\title{
Reaction of Phosphines with 1-Azido-(2-halogenomethyl)benzene Giving Aminophosphonium-Substituted Indazoles
}

Thibault Tannoux, ${ }^{a}$ Nicolas Casaretto, ${ }^{a}$ Sophie Bourcier, ${ }^{a}$ Vincent Gandon ${ }^{\mathrm{a}, \mathrm{b} *}$ and Audrey Auffrant ${ }^{\mathrm{a} *}$

a Laboratoire de Chimie Moléculaire, CNRS UMR 9168, École Polytechnique, Institut Polytechnique de Paris, 91128 Palaiseau, France

audrey.auffrant@polytechnique.edu

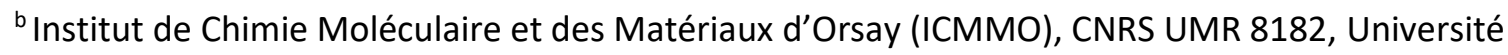
Paris-Saclay, Bâtiment 420, 91405 Orsay cedex, France

vincent.gandon@universite-paris-saclay.fr

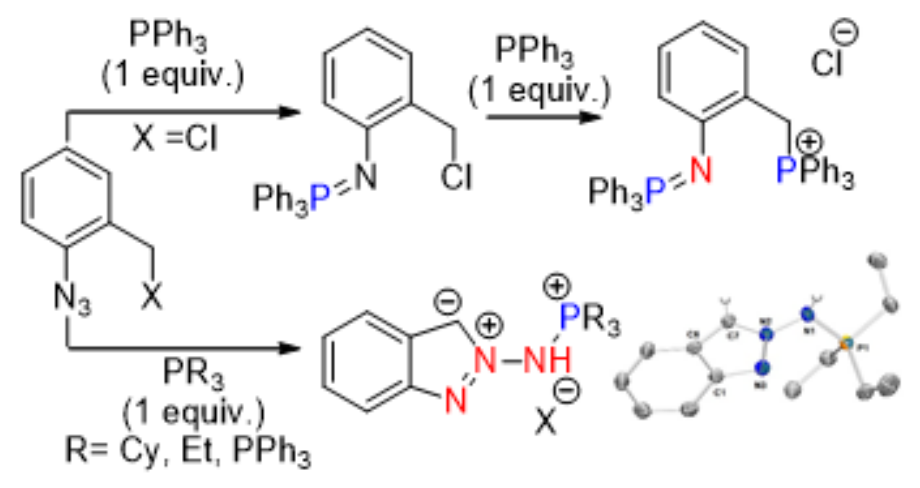

Abstract: The reaction between a 1-azido-(2-halogenomethyl)benzene and a phosphine gives different products depending on the nature of the halogen, the phosphine itself and the solvent employed. While $\mathrm{PPh}_{3}$ (2 equiv.) reacts with the chloro reagent in toluene to give the expected iminophosphorane-phosphonium adduct, trialkylphosphines $\left(\mathrm{PCy}_{3}\right.$ and $\left.\mathrm{PEt}_{3}\right)$ surprisingly furnish an aminophosphonium substituted by a zwitterionic indazole. The bicyclic product can also form from $\mathrm{PPh}_{3}$ using the bromo reagent in acetonitrile. A mechanism is proposed for this cyclization based on DFT calculations.

In a seminal paper dating back to 1919 , J. Meyer and $\mathrm{H}$. Staudinger reported that the reaction between a phosphine and an azide delivers a phosphinimine (or iminophosphorane) derivative featuring a $\mathrm{P}=\mathrm{N}$ bond, after release of $\mathrm{N}_{2}$ gas. 1 This transformation has found numerous applications in organic synthesis ${ }^{2}$ and also in chemical biology with the preparation of bioconjugates by the so-called Staudinger ligation. $^{3}$ The involvement of phosphazides (Figure 1), initially postulated by Meyer and Staudinger, has been proved and its decomposition with loss of $\mathrm{N}_{2}$ has been investigated. ${ }^{4}$ While they were first described as transient species, it has been demonstrated that they can be stabilized via the proper choice of the phosphorus substituents or by coordination to metals or main group elements. ${ }^{5}$ Moreover, their trapping with a variety of $\mathrm{C}-\mathrm{sp}^{2}$ electrophiles leading to nitrogen heterocycles has also been explored. ${ }^{6}$ Of note, the Staudinger reaction has also been largely employed by chemists interested in the development of iminophosphorane based ligands. $^{7}$

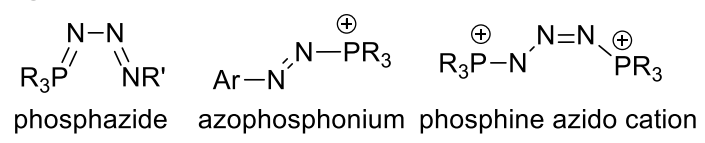

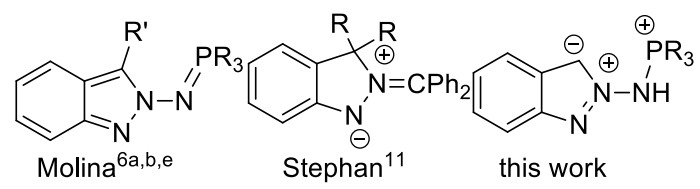

Figure 1 Examples of azo or azido containing compounds

In this report we describe our study of the reaction of a phosphine with a 1-azido-(2halogenomethyl)benzene which, depending on 
the nature of the phosphine, the halide, and the solvent, yields either the expected iminophosphorane $\mathbf{1}$ or, surprisingly, the aminophosphonium substituted indazole $\mathbf{2}$ (Scheme 1).

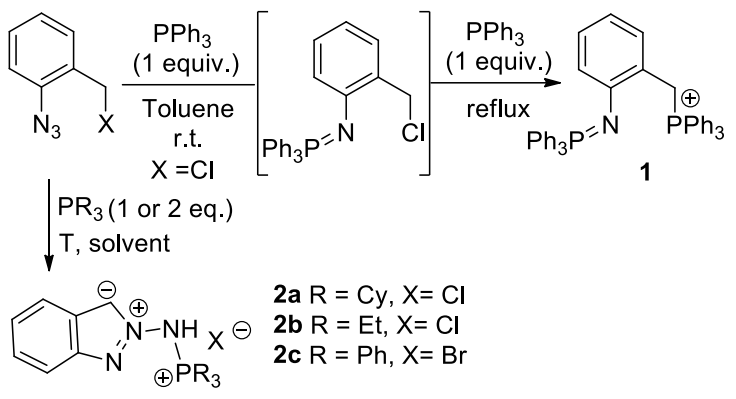

Scheme 1: Reaction of 1-azido-(2methylhalogeno)benzene with phosphines

The latter belongs to the small family of organic molecules combining azo or azido fragments with phosphorus atoms (Figure 1). The deprotonation of the aminophosphonium derivatives $\mathbf{2}$ to give the corresponding iminosphosphoranes $\mathbf{3}$ is also described. A mechanism is proposed, based on DFT calculations, to explain the formation of the cyclic products 2 .

Addition of triphenylphosphine ( 1 equiv.) to a toluene solution of 1-azido-(2chloromethyl)benzene at room temperature induced a strong nitrogen evolution (Scheme 1). After overnight stirring, the ${ }^{31} \mathrm{P}\left\{{ }^{1} \mathrm{H}\right\} \mathrm{NMR}$ monitoring of the supernatant evidenced the formation of the iminophosphorane $(\delta=0.3$ $\mathrm{ppm}$ ) and some unreacted $\mathrm{PPh}_{3}$ in a ratio close to 95:5. A white precipitate also appeared indicating that the bifunctional iminophosphorane phosphonium derivative 1 started to form. To isolate $\mathbf{1}$, a second equivalent of triphenylphosphine was added and the reaction mixture was heated to reflux for $24 \mathrm{~h}$ to favor the substitution of the chloride by $\mathrm{PPh}_{3}$. Thus, the iminophosphorane is formed prior to the chlorine substitution. Alternatively, the reaction can also be performed by adding directly 2 equiv. of $\mathrm{PPh}_{3}$ and compound 1 precipitates out of the reaction mixture. The ${ }^{31} \mathrm{P}\left\{{ }^{1} \mathrm{H}\right\}$ NMR spectrum of this compound in $\mathrm{CD}_{2} \mathrm{Cl}_{2}$ shows two singlets at 7.6 and $20.4 \mathrm{ppm}$ corresponding respectively to the $\mathrm{R}_{3} \mathrm{P}=\mathrm{N}$ and the phosphonium groups. Aside from several aromatic resonances, the ${ }^{1} \mathrm{H}$ NMR spectrum exhibits a doublet at $5.14 \mathrm{ppm}\left({ }^{2} \mathrm{~J}_{\mathrm{P}, \mathrm{H}}=13.5 \mathrm{~Hz}\right)$ corresponding to the two benzylic protons, which is in the range of data reported for benzyltriphenylphosphonium derivatives. ${ }^{8}$

The structure of 1 was confirmed by X-ray diffraction (Figure S1). The iminophosphorane and the phosphonium moieties exhibit bond lengths and angles which are typical for such functional groups. Of note, no interaction between the electron-rich nitrogen and the electron-deficient phosphonium group was observed in the solid state. On the contrary, the methylene-phosphonium group is almost orthogonal to the mean plan containing the aromatic ring and the iminophosphorane moiety (dihedral angle: $84.99^{\circ}$, see Figure S1).

A large amount of precipitate formed when the reaction was conducted with tricyclohexylphosphine ( 1 or 2 equiv.) at room temperature. ${ }^{31} \mathrm{P}\left\{{ }^{1} \mathrm{H}\right\} N \mathrm{NMR}$ monitoring of the supernatant did not show the formation of the expected iminophosphorane. Instead, only traces of $\mathrm{Cy}_{3} \mathrm{PO}$ could be observed, as well as remaining $\mathrm{PC}_{3}$ when 2 equivalents were used. In that latter case, heating the reaction mixture to favor the consumption of the phosphine did not change the composition of the supernatant. The formed solid was isolated and analyzed by multinuclear NMR. The ${ }^{31} \mathrm{P}\left\{{ }^{1} \mathrm{H}\right\}$ NMR spectrum showed only a deshielded singlet at $58.0 \mathrm{ppm}$ in $\mathrm{CD}_{2} \mathrm{Cl}_{2}$ and the ${ }^{1} \mathrm{H}$ NMR spectrum did not evidence any benzylic type proton. Instead, only aromatic and cyclohexyl resonances were observed, as well as a highly deshielded broad singlet at $8.41 \mathrm{ppm}$. The latter correlates with an aromatic resonance at $7.69 \mathrm{ppm}$ in the COSY ${ }^{1} \mathrm{H}-{ }^{1} \mathrm{H}$ spectrum, and the phosphorus signal in the hetercosy ${ }^{31} \mathrm{P}_{-}{ }^{1} \mathrm{H}$. The elemental composition of the molecular ion $(\mathrm{m} / \mathrm{z}$ 412.2875) obtained from HR-MS analysis is $\mathrm{C}_{25} \mathrm{H}_{39} \mathrm{~N}_{3} \mathrm{P}$, giving a yield of $78 \%$ for $2 \mathrm{a}$. Moreover, this ion loses $\mathrm{N}_{2}$ to give an ion at $\mathrm{m} / \mathrm{z}$ 384.2822 in Collision-Induced Dissociation (CID) experiments. This evidences that the $N_{3}$ 
motif is kept during the reaction. Definitive evidence regarding the structure of $2 a$ came from X-ray analysis (Figure S2). It can be described as an aminophosphoniumsubstituted indazole (Scheme 1). Although the charges are localized in Scheme 1 for clarity, the planarity of the molecule (Figure S2, torsion angle $66 \mathrm{C} 7 \mathrm{~N} 2 \mathrm{~N} 3: 0.74^{\circ}$ ) and the intermediate bond lengths measured within the bicycle (Table S3) reveal that the electron density is delocalized. We did not find any comparable P$\mathrm{NH}-\mathrm{N}-\mathrm{N}$ motif in the CCDC database, nor a tricyclohexyl aminophosphonium to compare with. Nevertheless, the P-N bond in 2a $(1.6502(16) \AA)$ is in the upper range of those reported for aminophosphonium derivatives. The endocyclic N2N3 bond, measured at $1.341(2) \AA$, is also rather long for a $\mathrm{N}=\mathrm{N}$ bond. It is indeed longer than the average length measured for azophosphoniums ${ }^{9}$ (1.272 $\AA$ on average), non-metallated phosphazides (1.277 $\AA$ on average) or phosphine azido cations ${ }^{10}$ (1.277 $\AA$ on average) available in the CCDC database (Figure 1). Such a bond length is reminiscent of the $\mathrm{N}-\mathrm{N}$ bond reported by Stephan's group in 2018 when deprotonating a cyclic (amino)(aryl)nitrenium cation $\alpha$ to the nitrogen (Figure 1) for which the $\mathrm{N}-\mathrm{N}$ bond length is $1.3584(14) \AA .{ }^{11}$ It should be noted that such a cyclic product was never observed when reacting $\mathrm{PC}_{3}$ with 2-(azidomethyl)-6(chloromethyl)pyridine. ${ }^{7 m}$ Here, the cyclization is probably driven by the stability of the indazole structure and the electron delocalization within the molecule. Indeed, 2a can be stored in vials on the bench and the ${ }^{31} \mathrm{P}\left\{{ }^{1} \mathrm{H}\right\}$ of its solution in chloroform or dichloromethane does not change within 1 or 2 days.

In order to determine whether the indazole could form with a less sterically hindered phosphine, the same reaction was conducted with $\mathrm{PEt}_{3}$. ${ }^{31} \mathrm{P}\left\{{ }^{1} \mathrm{H}\right\} \quad \mathrm{NMR}$ analysis of the supernatant of the crude reaction mixture obtained from toluene with 1 equiv. of $\mathrm{PEt}_{3}$ showed several resonances. Nevertheless, NMR analysis of the precipitate evidenced 3 products, among which the major ones exhibits a singlet ${ }^{31} \mathrm{P}\left\{{ }^{1} \mathrm{H}\right\}$ resonance at $68.9 \mathrm{ppm}$, which fits with the ${ }^{31} \mathrm{P}$ chemical shift reported for aminotriethylphosphonium. ${ }^{12}$ Reasoning that the substitution reaction should be easier in more polar solvent, the reaction was repeated in acetonitrile, leading to less side products. The major compound labelled $\mathbf{2} \mathbf{b}$ could be isolated in $65 \%$ yield by precipitation in toluene and its characterization by multinuclear NMR pointed to a structure similar to $\mathbf{2} \mathbf{a}$. The structure of $\mathbf{2} \mathbf{b}$ was also confirmed by X-ray diffraction analysis (see Figure S3). The bond lengths and angles are very similar to those of $\mathbf{2 a}$ (Table S3).

The formation of the indazole from $\mathrm{PPh}_{3}$ was also attempted with the seemingly more electrophilic 1-azido-(2bromomethyl)benzene. When the reaction was conducted in toluene at room temperature, a mixture of at least 4 different products was obtained, but its analysis by HRMS spectrometry evidenced the presence a compound of type $\mathbf{2}$. The aminophosphonium substituted indazole $\mathbf{2} \mathbf{c}$ could finally be isolated in $73 \%$ yield by reacting $\mathrm{PPh}_{3}$ and 1-azido-(2methylbromo)benzene in acetonitrile, from which the product precipitated out. $\mathbf{2 c}$ was characterized by multinuclear NMR, HR-MS measurement and $\mathrm{X}$-ray crystallography (Figure S4). The bond lengths and angles are similar to those of $\mathbf{2} \mathbf{a}$ and $\mathbf{2} \mathbf{b}$ except the NNP angle, which is more acute than that previously observed (116.25 ${ }^{\circ}$ vs $119.78^{\circ}$ on average).

Other phosphines were tested without success: $\mathrm{PMe}_{3}$ gave a mixture of inseparable products whatever the solvent used, and $\mathrm{PMes}_{3}$ remained unreactive even towards the bromide electrophile in refluxing acetonitrile.

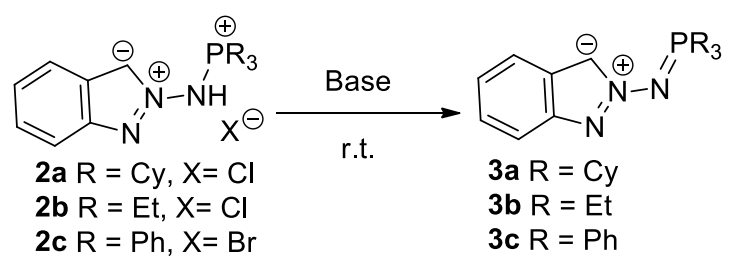

Scheme 2: Preparation of iminophosphorane 3a-c 
Iminophosphorane derivatives 3a-c were prepared by deprotonation of aminophosphoniums 2a-c (Scheme 2). These compounds resemble the nitrogen heterocycles described by Molina and coworkers $^{6 \mathrm{a}, 6 \mathrm{~b}, 6 \mathrm{e}}$ (Figure 1), except the absence of substituent at the benzylic carbon. Depending on the solubility of the formed iminophosphorane in organic solvents, the reaction was performed either with a stoichiometric amount of KHMDS in THF or with BuLi in $\mathrm{Et}_{2} \mathrm{O}$. Some compound was lost during workup, explaining the modest yield obtained for $3 a$ and 3 c $(40 \%$ and $57 \%$ respectively). In ${ }^{31} \mathrm{P}\left\{{ }^{1} \mathrm{H}\right\}$ NMR spectra, the deprotonation induces a large shielding of the phosphorus nucleus with ${ }^{31} \mathrm{P}\left\{{ }^{1} \mathrm{H}\right\}$ resonances at $34.4,37.1$, and $11.3 \mathrm{ppm}$ for 3a-c respectively. On the contrary, the ${ }^{1} \mathrm{H}$ resonance of the benzylic hydrogen is only slightly shielded $(\Delta \delta$ between -0.1 and $-0.4 \mathrm{ppm}$ ) as is the corresponding ${ }^{13} \mathrm{C}\left\{{ }^{1} \mathrm{H}\right\}$ resonance, but a large increase of the $J_{P, C}$ coupling constant from 3.0 $\mathrm{Hz}$ in 2 to $13.5-14.5 \mathrm{~Hz}$ in $\mathbf{3}$ was observed. The structures of $\mathbf{3 a}$ and $\mathbf{3 c}$ were analyzed by $\mathrm{X}$-ray diffraction. They are very similar to those of $\mathbf{2 a}$ (Figures S5, S6, and Table S3). The deprotonation is accompanied by an expected shortening of the PN bonds (1.6130(6) and 1.6002(14) A in 3a and 3c respectively), which falls in the range of those commonly observed for iminophosphoranes. Otherwise, bonds and angles measured are similar to those of the corresponding aminophosphonium, except a slight shortening of the exocyclic NN bond (1.372(3) vs 1.388(2) Å) observed in 3a.

In order to shed light on the mechanism of formation of 2, DFT calculations were conducted at the M06-2X/6$311++G(2 d, p) / / M 06-2 X / 6-31(d)$ level of theory (see the Supporting Information for details). Two different mechanisms can be proposed. The first one consists in an initial substitution of the halide by the phosphine followed by a proton transfer, a nucleophilic attack of the benzylic carbon on the central nitrogen, and a
1,3 carbon to nitrogen shift of the $\mathrm{PR}_{3}$ fragment (Scheme 3, path a).

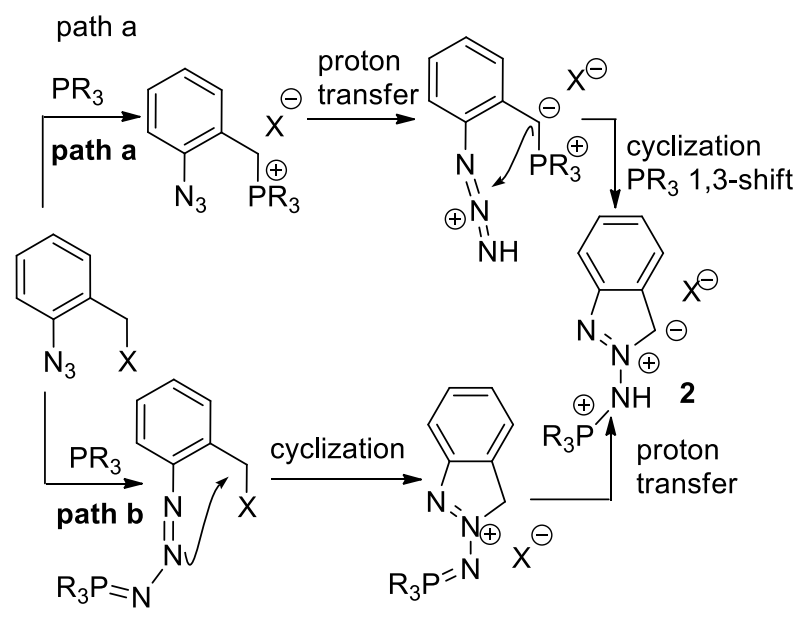

Scheme 3: Mechanistic pathways to form 2

The second pathway involves the nucleophilic attack of the central $\mathrm{N}$ atom of the intermediate phosphazide onto the benzylic carbon followed by a proton transfer (Scheme 3 , path b). These two mechanistic options were investigated with two model phosphines $\left(\mathrm{PMe}_{3}\right.$ and $\left.\mathrm{PPh}_{3}\right)$ and two electrophiles $(\mathrm{X}=\mathrm{Cl}, \mathrm{Br}$, see the Supporting Information). For path $a$, the substitution of the halide could be computed with activation barrier of $23.5\left(\mathrm{PMe}_{3}\right)$ and 26.5 $\mathrm{kcal} \mathrm{mol}^{-1}\left(\mathrm{PPh}_{3}\right)$ for the chloride, and 17.3/20.3 $\mathrm{kcal} \mathrm{mol}^{-1}$ for the bromide substitution (Scheme S2, Int1 to Int6). Nevertheless, the subsequent proton transfer could not be calculated. The formation of the final products from the azidoylides could be calculated in 3 steps (Scheme S3, Int7 to Int13) but the 1,3 transfer of the phosphine group faces an unsurmountable barrier $\left(\Delta \mathrm{G}_{298} \geq 40 \mathrm{kcal} \mathrm{mol}^{-1}\right)$, which is typical of a symmetry-forbidden 1,3-shift. The second option for the formation of the experimentally observed products (Scheme 3, path b) starts with the addition of the phosphine to the terminal nitrogen of the $\mathrm{N}_{3}$ framework to give the corresponding azidophosphoniums Int1417 (Figure 2). In the chlorine series, the transition states lie at lower energies than those of the $\mathrm{SN}_{2}$ pathway (21.6 vs $23.5,24.4$ vs $\left.26.5 \mathrm{kcal} \mathrm{mol}^{-1}\right)$. On the other hand, the direct substitution of the bromine by the phosphine remains a faster process (21.7 vs 17.3, 23.9 vs $\left.20.4 \mathrm{kcal} \mathrm{mol}^{-1}\right)$. Compounds Int14-17 are 


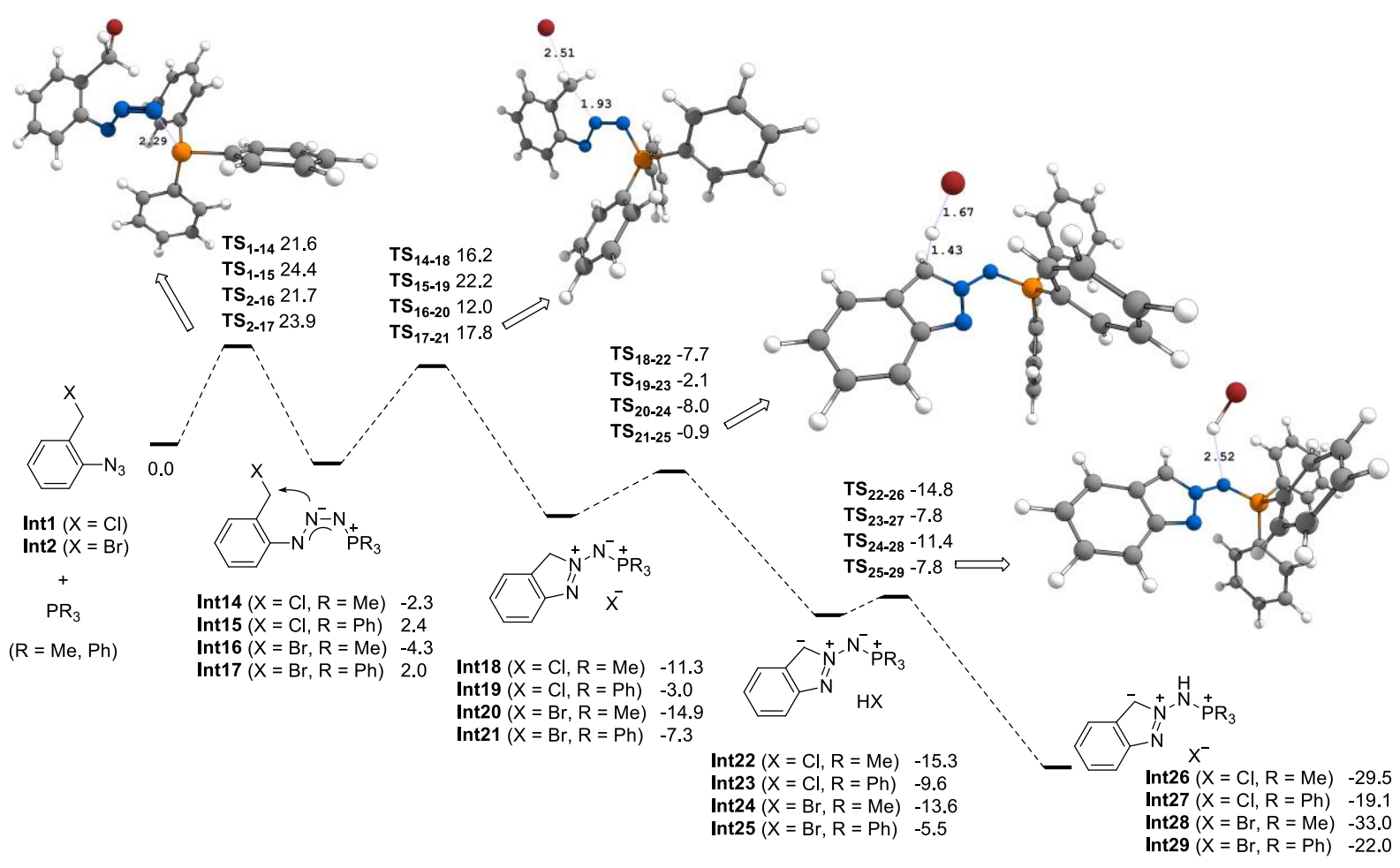

Figure 2: Free energy profile of the formation of the final products Int26-29 from azidophosphoniums $\left(\Delta \mathrm{G}_{298}\right.$, kcal mol-1; selected distances in $\AA$ )

obtained in a s-cis configuration, which is more stable than the s-trans one by $\sim 3-4 \mathrm{kcal} \mathrm{mol}^{-1} .{ }^{13}$ These adducts are slightly more stable than the reactants with $\mathrm{PMe}_{3}$ and slightly less with $\mathrm{PPh}_{3}$. Substitution of the halide by the central nitrogen proceeds through transition states that are all more stable than those computed in the $\mathrm{SN}_{2}$ case (Figure 2 and Scheme S3). As one could expect, displacement of the bromine is easier than that of the chlorine. This step is faster and more exergonic with the alkylphosphine $\mathrm{PMe}_{3}$ than $\mathrm{PPh}_{3}$. The proton transfer was modeled as a two-step downhill process using the halide as a base. Deprotonation of Int18-21 is straightforward with barrier ranging from 1 to $7 \mathrm{kcal} \mathrm{mol}^{-1}$. The protonation of the terminal nitrogen is also achieved at a low free energy cost of $\sim 1-2 \mathrm{kcal}$ $\mathrm{mol}^{-1}$. The overall exergonicities are higher with $\mathrm{PMe}_{3}\left(-29.5 /-33.0 \mathrm{kcal} \mathrm{mol}{ }^{-1}\right)$ than with $\mathrm{PPh}_{3}(-$ $\left.19.1 /-22.0 \mathrm{kcal} \mathrm{mol}^{-1}\right)$. Thus, path $\mathrm{b}$ in Scheme 3 better explains the formation of the final products. On both kinetic and thermodynamic grounds, an alkylphosphine such as $\mathrm{PMe}_{3}$ is more likely to follow this pathway than a less electron-rich phosphine such as $\mathrm{PPh}_{3}$.
In conclusion, we evidenced that the reaction of a phosphine with 1-azido-(2halogenomethyl)benzene depends on the substituents of the $P$ atom, the nature of the halide and the operating conditions. While iminophosphorane can be obtained from triphenylphosphine and 1-azido-(2chloromethyl)benzene in toluene, allowing to isolate an iminophosphorane-phosphonium derivative using 2 equiv. of $\mathrm{PPh}_{3}, \mathrm{PCy}_{3}$ and $\mathrm{PEt}_{3}$ do not give the iminophosphorane linkage. Instead, a bicyclic compound $\mathbf{2}$ is obtained. Such a compound can also be isolated from $\mathrm{PPh}_{3}$ using a better leaving group on the carbon and a more polar solvent. The mechanism of this cyclization was investigated by DFT calculations; the nucleophilic attack of the phosphazide onto the electrophilic carbon appearing as the more favorable pathway. Iminophosphoranes $\mathbf{3}$ were then obtained by deprotonation of aminophosphonium 2. These derivatives exhibit two electron rich atoms: the nitrogen of the $\mathrm{P}=\mathrm{N}$ and the benzylic carbon. It would therefore be interesting to study their reactivity towards organometallic or organic electrophiles and Lewis acids. Remarkably, 
more than a century after its discovery, Staudinger type reaction can still open access to unprecedented chemical structures.

\section{Experimental section}

General considerations. All reactions were conducted under an atmosphere of dry nitrogen, or argon, using standard Schlenk and glovebox techniques. Solvents and reagents were obtained from commercial sources. Solvents were dried with a M-Braun MB-SPS 800 solvent purification system. Deuterated solvents were used as received and stored over molecular sieves. All other reagents and chemicals were obtained commercially and used without further purification. Nuclear Magnetic Resonance (NMR) spectra were recorded on a Bruker Avance 300 spectrometer operating at $300 \mathrm{MHz}$ for ${ }^{1} \mathrm{H}, 75.5 \mathrm{MHz}$ for ${ }^{13} \mathrm{C}$ and $121.5 \mathrm{MHz}$ for ${ }^{31} \mathrm{P}$. Solvent peaks were used as internal references for ${ }^{1} \mathrm{H}$ and ${ }^{13} \mathrm{C}\left\{{ }^{1} \mathrm{H}\right\}$ chemical shifts (ppm). ${ }^{31} \mathrm{P}\left\{{ }^{1} \mathrm{H}\right\}$ NMR spectra are relative to a $85 \% \mathrm{H}_{3} \mathrm{PO}_{4}$ external reference. Unless otherwise mentioned, NMR spectra were recorded at $300 \mathrm{~K}$. Structural assignments were made with additional information from gCOSY, gHSQC, and gHMBC experiments. Coupling constant are expressed in hertz. The following abbreviations are used: br, broad; $s$, singlet; $d$, doublet; q: quadruplet; $t$, triplet; $m$, multiplet; $v$, virtual. The spectra were analyzed with MestReNova software. IR spectra were recorded on a IR-TF Thermo Scientific Nicolet is5 spectrometer. Mass spectrometry experiments were recorded on tims-TOF mass spectrometer (Bruker, France). Samples are prepared in $\mathrm{CH}_{3} \mathrm{CN}$ and introduced at $5 \mu \mathrm{L}$. $\mathrm{min}^{-}$ ${ }^{1}$ flow rate into the electrospray ion (ESI) source in positive mode. Both full scan (MS) and collision induced dissociation (CID) mass spectra have been carried for the compound characterization. In MS/MS experiment, the precursor ion was selected with an isolation window of $2 \mathrm{Da}$ and the collision induced dissociation was performed using $20 \mathrm{eV}$ as collision energy. Tuning mix (Agilent, France) was used for calibration. Accurate masses and elemental compositions were obtained using the DataAnalysis software. The elemental compositions were obtained with a tolerance below $5 \mathrm{ppm}$.
Preparation of 1: To as solution of 1-azido-2(chloromethyl)benzene ${ }^{14} \quad(341.8 \mathrm{mg}, \quad 2.04$ $\mathrm{mmol})$ in toluene $(20 \mathrm{~mL})$ was added triphenylphosphine $(1.07 \mathrm{~g}, 4.08 \mathrm{mmol})$. After stirring the reaction mixture at room temperature under nitrogen stream overnight, the in situ ${ }^{31} \mathrm{P}\left\{{ }^{1} \mathrm{H}\right\}$ NMR spectrum of slight suspension evidences the formation of the iminophosphorane function ( $\delta=0.4 \mathrm{ppm}$ ) and remaining triphenylphosphine. The reaction mixture was then heated at reflux with an oil bath, reinforcing the precipitation of a white solid. The reaction was stopped when only traces of triphenylphosphine are observed by in situ ${ }^{31} \mathrm{P}\left\{{ }^{1} \mathrm{H}\right\}$ NMR. The white solid was isolated by filtration, washed with toluene ( 20 $\mathrm{mL}$ ) and dried to give compound $\mathbf{1}(1.2 \mathrm{~g}, 90 \%)$. Single crystals of 1 were obtained by slow diffusion of pentane into a concentrated dichloromethane solution of the compound. ${ }^{31} \mathrm{P}$ NMR (121.5 MHz, $\mathrm{CD}_{2} \mathrm{Cl}_{2}$ ): $\delta 7.6(\mathrm{~s}, \mathrm{~N}=\mathrm{P})$, 20.4 (s, P'II). ${ }^{1} \mathrm{H}$ NMR (300 MHz, $\mathrm{CD}_{2} \mathrm{Cl}_{2}$ ): $\delta 7.79$ (br. t, $J_{H, H}=7.5 \mathrm{~Hz}, J_{P, H}=7.0 \mathrm{~Hz}, 3 \mathrm{H}, \mathrm{CH}\left(\mathrm{PPh}_{3}\right)$ ), 7.70-7.40 (m, $\left.24 \mathrm{H}, \mathrm{CH}\left(\mathrm{PPh}_{3}\right)\right), 6.87$ (br. d, $J_{H, H}=$ $7.5 \mathrm{~Hz}, 1 \mathrm{H}, \mathrm{CH}(\mathrm{Ar})$ )), 6.82 (br. d, $J_{H, H}=8.5 \mathrm{~Hz}, 1 \mathrm{H}$, $\mathrm{CH}(\mathrm{Ar})), 6.49\left(\mathrm{vt}, J_{H, H}=J_{P, H}=7.5 \mathrm{~Hz}, 1 \mathrm{H}, \mathrm{CH}(\mathrm{Ar})\right)$, $6.33\left(\mathrm{~d}, J_{H, H}=8 \mathrm{~Hz}, 1 \mathrm{H}, \mathrm{CH}(\mathrm{Ar})\right), 5.14\left(\mathrm{~d}, J_{P, H}=\right.$ $\left.13.5 \mathrm{~Hz}, \mathrm{CH}_{2}\right) .{ }^{13} \mathrm{C}\left\{{ }^{1} \mathrm{H}\right\}$ NMR $\left(75.5 \mathrm{MHz}, \mathrm{CD}_{2} \mathrm{Cl}_{2}\right)$ : $\delta 151.2\left(\mathrm{~d}, J_{P, C}=5 \mathrm{~Hz}, \mathrm{C}^{\mathrm{IV}}-\mathrm{N}\right), 134.9\left(\mathrm{~d}, J_{P, C}=3.0\right.$ $\left.\mathrm{Hz}, \mathrm{CH}\left(\mathrm{PPh}_{3}\right)\right), 134.1\left(\mathrm{~d}, \mathrm{~J}_{P, C}=9.5 \mathrm{~Hz}, \mathrm{CH}\left(\mathrm{PPh}_{3}\right)\right)$, $132.4\left(\mathrm{~d}, J_{P, C}=10.0 \mathrm{~Hz}, \mathrm{CH}\left(\mathrm{PPh}_{3}\right)\right), 132.2\left(\mathrm{~d}, J_{P, C}\right.$ $\left.=3.0 \mathrm{~Hz}, \mathrm{CH}\left(\mathrm{PPh}_{3}\right)\right), 130.3\left(\mathrm{~d}, J_{P, C}=5.5 \mathrm{~Hz}\right.$, $\mathrm{CH}(\mathrm{Ar})), 130.0\left(\mathrm{~d}, J_{P, C}=12.5 \mathrm{~Hz}, \mathrm{CH}\left(\mathrm{PPh}_{3}\right)\right)$, $129.7\left(\mathrm{~d}, J_{P, C}=100.0 \mathrm{~Hz}, \mathrm{C}^{\mathrm{IV}}\left(\mathrm{PPh}_{3}\right)\right), 129.1\left(\mathrm{~d}, J_{P, C}\right.$ $=4.0 \mathrm{~Hz}, \mathrm{CH}(\mathrm{Ar})), 128.8\left(\mathrm{~d}, J_{P, C}=12.0 \mathrm{~Hz}\right.$, $\left.\mathrm{CH}\left(\mathrm{PPh}_{3}\right)\right), 121.4\left(\mathrm{~d}, J_{P, C}=10.5 \mathrm{~Hz} \mathrm{~Hz}, \mathrm{CH}(\mathrm{Ar})\right)$, 129.7 (obs. by 2D NMR, $\left.C^{1 V}(A r)\right), 118.7$ (dd, $J_{P, C}$ $\left.=85.0 \mathrm{~Hz} \mathrm{~Hz}, \mathrm{C}^{\mathrm{IV}}\left(\mathrm{PPh}_{3}\right)\right), 117.3\left(\mathrm{~d}, J_{P, C}=3.5 \mathrm{~Hz}\right.$, $\mathrm{CH}(\mathrm{Ar})), 26.9\left(\mathrm{~d}, J_{P, C}=49.0 \mathrm{~Hz}, \mathrm{CH}_{2}\right)$. IR (neat, $\left.\mathrm{cm}^{-1}\right)$ : 2360, 1588, 1479, 1347 (N=P), 1111. HRMS (ESI $/ \mathrm{Q}-\mathrm{TOF}) \mathrm{m} / \mathrm{z}$ : [1-Cl] ${ }^{+}$Calcd for $\mathrm{C}_{43} \mathrm{H}_{36} \mathrm{NP}_{2}{ }^{+}$628.2318; Found 628.2319.

Preparation of $2 a$. A solution of $\mathrm{PCy}_{3}(560 \mathrm{mg}$, $2.0 \mathrm{mmol})$ in toluene $(3 \mathrm{~mL})$ was added to a solution of 1-azido-2-(chloromethyl)benzene (335 mg, $2.0 \mathrm{mmol}$ ) in toluene $(15 \mathrm{~mL}$ ). The 
reaction mixture was stirred overnight at room temperature and then heated to reflux for $1 \mathrm{~h}$ with an oil bath to complete the reaction. The precipitate was filtered and washed with toluene $(5 \times 5 \mathrm{~mL})$ to deliver $2 \mathrm{a}$ as an off-white colored solid (649 mg, $1.55 \mathrm{mmol}, 78 \%$ ). Single crystals of $2 \mathrm{a}$ were obtained by slow diffusion of pentane into a concentrated dichloromethane solution of the compound. ${ }^{31} \mathrm{P}$ NMR (121.5 MHz, $\mathrm{CD}_{2} \mathrm{Cl}_{2}$ ): $\delta 58.0$ (s). ${ }^{1} \mathrm{H}$ NMR (300 MHz, $\mathrm{CD}_{2} \mathrm{Cl}_{2}$ ): $\delta 8.37$ (br. $\mathrm{S}, 1 \mathrm{H}, \mathrm{CH}-$ N), 7.61 (br. t, $\left.J_{H, H}=9.0 \mathrm{~Hz}, 2 \mathrm{H}, \mathrm{CH}(\mathrm{Ar})\right), 7.28$ (br. t, $J_{H, H}=7.5 \mathrm{~Hz}, 1 \mathrm{H}, \mathrm{CH}(\mathrm{Ar})$ ), 7.09 (br. t, $J_{H, H}=$ $7.5 \mathrm{~Hz}, 1 \mathrm{H}, \mathrm{CH}(\mathrm{Ar}), 2.80\left(\mathrm{vq}, J_{H, H}=J_{P, H}=12.5 \mathrm{~Hz}\right.$ $\left.J_{H, H}=2.5 \mathrm{~Hz}, 3 \mathrm{H}, \mathrm{CH}(\mathrm{Cy})\right), 2.11-1.26(\mathrm{~m}, 30 \mathrm{H}$, $\left.\mathrm{CH}_{2}(\mathrm{Cy})\right) .{ }^{13} \mathrm{C}\left\{{ }^{1} \mathrm{H}\right\}$ NMR $\left(75.5 \mathrm{MHz}, \mathrm{CD}_{2} \mathrm{Cl}_{2}\right): \delta$ 145.5 (s, C C $-\mathrm{N}), 125.9$ (s, CH(Ar), 121.9 (s, $\mathrm{CH}(\mathrm{Ar}), 120.7$ (d, $J_{P, C}=3.0 \mathrm{~Hz}, \mathrm{CH}-\mathrm{N}$ ), 120.8 (s, $\left.\mathrm{C}^{\mathrm{IV}}-\mathrm{C}\right), 119.9$ (s, $\mathrm{CH}(\mathrm{Ar}), 116.7$ (s, $\mathrm{CH}(\mathrm{Ar}), 33.1$ (d, $\left.J_{P, C}=47.0 \mathrm{~Hz}, \mathrm{CH}(\mathrm{Cy})\right), 26.7\left(\mathrm{~d}, J_{P, C}=13.0 \mathrm{~Hz}\right.$, $\mathrm{CH}(\mathrm{Cy})), 26.5\left(\mathrm{~d}, \mathrm{~J}_{P, C}=3.0 \mathrm{~Hz}, \mathrm{CH}(\mathrm{Cy})\right), 25.5$ (s, $\mathrm{CH}(\mathrm{Cy})$ ). IR (neat, $\mathrm{cm}^{-1}$ ): 2928, 2852, 2361, 2342, 1444, 1006. HRMS (ESI $\left.{ }^{+} / \mathrm{Q}-\mathrm{TOF}\right)$ ) $\mathrm{m} / \mathrm{z}$ : [2a-Cl] ${ }^{+}$Calcd for $\mathrm{C}_{25} \mathrm{H}_{39} \mathrm{~N}_{3} \mathrm{P}^{+}$412.2876; Found 412.2885.

Preparation of $\mathbf{2 b}$. A solution of $\mathrm{PEt}_{3}(237.7 \mathrm{mg}$, $2.01 \mathrm{mmol})$ in $\mathrm{CH}_{3} \mathrm{CN}(3 \mathrm{~mL})$ was added to a solution of 1-azido-2-(chloromethyl)benzene (337.2 mg, $2.01 \mathrm{mmol}$ ) in $\mathrm{CH}_{3} \mathrm{CN}(7 \mathrm{~mL})$. The reaction mixture was stirred overnight at room temperature. The solvent was then evaporated and the residue was washed with toluene $(2 \times 10$ $\mathrm{mL}), \operatorname{THF}(2 \times 10 \mathrm{~mL})$ to deliver $\mathbf{2} \mathbf{b}$ as an off-white solid (372 mg, $1.30 \mathrm{mmol}, 65 \%$ ). Single crystals of $\mathbf{2} \mathbf{b}$ were obtained by slow diffusion of pentane into a concentrated dichloromethane solution of the compound. ${ }^{31} \mathrm{P}$ NMR (121.5 $\mathrm{MHz}, \mathrm{CD}_{2} \mathrm{Cl}_{2}$ ): $\delta 68.9$ (s). ${ }^{1} \mathrm{H}$ NMR (300 MHz, $\mathrm{CD}_{2} \mathrm{Cl}_{2}$ ): $\delta 8.20$ (br. s, $1 \mathrm{H}, \mathrm{CH}-\mathrm{N}$ ), 7.64 (dd, $J_{H, H}=$ $\left.8.5 \mathrm{~Hz}, J_{H, H}=1.0 \mathrm{~Hz}, 1 \mathrm{H}, \mathrm{CH}(\mathrm{Ar})\right), 7.60\left(\mathrm{dd}, J_{H, H}=\right.$ $\left.8.5 \mathrm{~Hz}, J_{H, H}=1.0 \mathrm{~Hz}, 1 \mathrm{H}, \mathrm{CH}(\mathrm{Ar})\right), 7.31$ (ddd, $J_{H, H}$ $=8.5$ and $\left.7.0 \mathrm{~Hz}, J_{H, H}=1.0 \mathrm{~Hz}, 1 \mathrm{H}, \mathrm{CH}(\mathrm{Ar})\right), 7.11$ (ddd, $J_{H, H}=8.5$ and $7.0 \mathrm{~Hz}, J_{H, H}=1.0 \mathrm{~Hz}, 1 \mathrm{H}$, $\mathrm{CH}(\operatorname{Ar})), 2.49\left(\mathrm{dq}, J_{H, H}=7.5 \mathrm{~Hz}, J_{P, H}=15.5 \mathrm{~Hz}, 6\right.$ $\left.\mathrm{H}, \mathrm{CH}_{2}\right), 1.30\left(\mathrm{dt}, J_{H, H}=7.5 \mathrm{~Hz}, J_{P, H}=19.5 \mathrm{~Hz}, 9\right.$ $\left.\mathrm{H}, \mathrm{CH}_{3}\right) .{ }^{13} \mathrm{C}\left\{{ }^{1} \mathrm{H}\right\}$ NMR $\left(75.5 \mathrm{MHz}, \mathrm{CD}_{2} \mathrm{Cl}_{2}\right): \delta$ $146.1\left(\mathrm{~s}, \mathrm{C}^{\mathrm{IV}}-\mathrm{N}\right), 126.4(\mathrm{~s}, \mathrm{CH}(\mathrm{Ar})), 122.3(\mathrm{~s}$, $\mathrm{CH}(\mathrm{Ar})), 121.5\left(\mathrm{~d}, \mathrm{~J}_{P, C}=3.0 \mathrm{~Hz}, \mathrm{CH}-\mathrm{N}\right), 120.7$ (s,
$\left.\mathrm{C}^{\mathrm{IV}}-\mathrm{C}\right), 120.0(\mathrm{~s}, \mathrm{CH}(\mathrm{Ar})), 116.8(\mathrm{~s}, \mathrm{CH}(\mathrm{Ar})), 14.7$ (d, $J_{P, C}=56.0 \mathrm{~Hz}, \mathrm{PCH}_{2}$ ), $5.28\left(\mathrm{~d}, J_{P, C}=5.0 \mathrm{~Hz}\right.$, $\mathrm{CH}_{3}$ ). IR (neat, $\mathrm{cm}^{-1}$ ): 3387, 2900, 2541, 2361, 1454, 1050. HRMS (ESI $\left.{ }^{+} / \mathrm{Q}-\mathrm{TOF}\right) \mathrm{m} / \mathrm{z}:[\mathbf{2 b}-\mathrm{Cl}]^{+}$ Calcd for $\mathrm{C}_{13} \mathrm{H}_{21} \mathrm{~N}_{3} \mathrm{P}^{+}$250.1468; Found 250.1467.

Preparation of 2c: Triphenylphosphine (266 $\mathrm{mg}, 1.05 \mathrm{mmol})$ was added to a solution of 1azido-2-(bromomethyl)benzene (221 mg, 1.04 $\mathrm{mmol}$ ) in acetonitrile $(3 \mathrm{~mL})$. After stirring 20 min., a white precipitate formed, and the solution was left to stir overnight at room temperature. The completion of the reaction was checked by ${ }^{31} \mathrm{P}$ NMR, showing no triphenylphosphine left. The solid was filtered and washed with toluene $(2 \times 3 \mathrm{~mL})$ to give the product as a white solid (361 mg, 73\%). Single crystals of $\mathbf{2 c}$ were obtained by slow diffusion of pentane into a concentrated dichloromethane solution of the compound. ${ }^{31} \mathrm{P} \mathrm{NMR}\left(121.5 \mathrm{MHz}, \mathrm{CDCl}_{3}\right)$ : 41.5. ${ }^{1} \mathrm{H}$ NMR (300 $\mathrm{MHz}, \mathrm{CDCl}_{3}$ ): 7.98 (br. s, $1 \mathrm{H}, \mathrm{CH}-\mathrm{N}$ ), 7.82 (td, $\mathrm{J}_{H, H}$ $\left.=7.5, J_{P, H}=13.5 \mathrm{~Hz}, 6 \mathrm{H}, \mathrm{CH}\left(\mathrm{PPh}_{3}\right)\right), 7.73\left(\mathrm{td}, J_{H, H}\right.$ $\left.=7.5, J_{P, H}=1.5 \mathrm{~Hz}, 3 \mathrm{H}, \mathrm{CH}\left(\mathrm{PPh}_{3}\right)\right), 7.56\left(\mathrm{td}, J_{H, H}=\right.$ $\left.7.5, J_{P, H}=4.0 \mathrm{~Hz}, 6 \mathrm{H}, \mathrm{CH}\left(\mathrm{PPh}_{3}\right)\right), 7.41\left(\mathrm{t}, J_{H, H}=\right.$ 7.5, 2H, CH(Ar)), $7.15(\mathrm{~m}, 1 \mathrm{H}, \mathrm{CH}(\mathrm{Ar})), 6.97(\mathrm{~m}$, $1 \mathrm{H}, \mathrm{CH}(\mathrm{Ar})) .{ }^{13} \mathrm{C}\left\{{ }^{1} \mathrm{H}\right\}$ NMR $\left(75.5 \mathrm{MHz}, \mathrm{CDCl}_{3}\right)$ : $145.9\left(\mathrm{~s}, \mathrm{C}^{\mathrm{IV}}-\mathrm{N}\right), 135.4\left(\mathrm{~d}, \mathrm{~J}_{P, C}=3.0 \mathrm{~Hz} \mathrm{CH}\left(\mathrm{PPh}_{3}\right)\right)$, $134.3\left(\mathrm{~d}, J_{P, C}=11.5 \mathrm{~Hz}, \mathrm{CH}\left(\mathrm{PPh}_{3}\right)\right), 129.8\left(\mathrm{~d}, J_{P, C}\right.$ $\left.=14.50 \mathrm{~Hz}, \mathrm{CH}\left(\mathrm{PPh}_{3}\right)\right), 126.4$ (s, $\left.\mathrm{CH}(\mathrm{Ar})\right), 123.6$ (d, $J_{P, C}=2.5 \mathrm{~Hz}, \mathrm{CH}-\mathrm{N}$ ), 122.3 (s, CH(Ar)), 120.7 $\left(\mathrm{s}, \mathrm{C}^{\mathrm{IV}}-\mathrm{C}\right), 120.0(\mathrm{~s}, \mathrm{CH}(\mathrm{Ar})) 118.9\left(\mathrm{~d},{ }^{1} \mathrm{~J}_{P, C}=102.0\right.$ $\mathrm{Hz}, \mathrm{C}^{\mathrm{IV}}-\mathrm{P}$ ), $117.3(\mathrm{CH}(\mathrm{Ar}))$. IR (neat, $\mathrm{cm}^{-1}$ ): 3075, 2563, 1628, 1586, 1483, 1438, 1403, 1377, 1323, 1111. HRMS (ESI $/ \mathrm{Q}-\mathrm{TOF}) \mathrm{m} / \mathrm{z}$ : $[2 \mathrm{c}-\mathrm{Br}]^{+}$ Calcd for $\mathrm{C}_{25} \mathrm{H}_{21} \mathrm{~N}_{3} \mathrm{P}^{+}$394.1468; Found 394.1477.

Preparation of 3a $(\mathrm{R}=\mathrm{Cy})$ : KHMDS $(60 \mathrm{mg}, 0.3$ $\mathrm{mmol}$ ) was added to a solution of $2 \mathrm{a}(148 \mathrm{mg}$, $0.3 \mathrm{mmol}$ ) in THF (4 mL). The solution became slightly yellow after $1 \mathrm{~h}$ stirring. The reaction mixture was then centrifugated. The solid was discarded and the solution was evaporated to dryness. The residue was washed with pentane $(2 \times 5 \mathrm{~mL})$ and dried to deliver $3 a$ as an offwhite solid (49 mg, 40\%). Single crystals of $3 a$ were obtained by slow evaporation of pentane 
solution of the compound. ${ }^{31} \mathrm{P}$ NMR (121.5 $\left.\mathrm{MHz}, \mathrm{C}_{6} \mathrm{D}_{6}\right): 34.4 .{ }^{1} \mathrm{H}$ NMR $\left(300 \mathrm{MHz}, \mathrm{C}_{6} \mathrm{D}_{6}\right): 8.03$ (br. s, $1 \mathrm{H}, \mathrm{CH}-\mathrm{N}), 7.83\left(\mathrm{~d}, J_{H, H}=8.5,1 \mathrm{H}, \mathrm{CH}(\mathrm{Ar})\right.$ ), $7.51\left(\mathrm{~d}, J_{H, H}=8.0,1 \mathrm{H}, \mathrm{CH}(\mathrm{Ar})\right), 7.22(\mathrm{~m}, 1 \mathrm{H}$, $\mathrm{CH}(\mathrm{Ar})), 7.03\left(\mathrm{t}, J_{H, H}=8.0 \mathrm{~Hz}, 1 \mathrm{H}, \mathrm{CH}(\mathrm{Ar})\right), 2.32$ $\left(\mathrm{vq}, J_{H, H}=J_{P, H}=12.0 \mathrm{~Hz}, 3 \mathrm{H}, \mathrm{CH}_{2}(\mathrm{Cy})\right), 1.91(\mathrm{~d}$, $\left.J_{H, H}=12.0 \mathrm{~Hz}, 6 \mathrm{H}, \mathrm{CH}(\mathrm{Cy})\right), 1.75-1.35(\mathrm{~m}, 16 \mathrm{H}$, $\mathrm{CH}(\mathrm{Cy}), 1.3-0.8(\mathrm{~m}, 8 \mathrm{H}, \mathrm{CH}(\mathrm{Cy})) .{ }^{13} \mathrm{C}\left\{{ }^{1} \mathrm{H}\right\} \mathrm{NMR}$ (75.5 MHz, $\left.\mathrm{C}_{6} \mathrm{D}_{6}\right): 145.3\left(\mathrm{C}^{\mathrm{IV}}-\mathrm{N}\right), 122.8$ (s, $\mathrm{CH}(\mathrm{Ar})), 122.5\left(\mathrm{~s}, \mathrm{C}^{\mathrm{IV}}-\mathrm{C}\right), 119.6(\mathrm{~s}, \mathrm{~s}, \mathrm{CH}(\mathrm{Ar}))$, 118.2 (s, CH(Ar)), 115.1 (d, JP,C $=13.5 \mathrm{~Hz}, \mathrm{CH}-\mathrm{N}$ ), 114.5 (s, $\mathrm{CH}(\mathrm{Ar})), 35.7\left(\mathrm{~d}, J_{P, C}=54.5 \mathrm{~Hz}\right.$, $\left.\mathrm{CH}_{2}(\mathrm{Cy})\right), 27.3$ (d, $\left.\mathrm{J}_{P, C}=4.0 \mathrm{~Hz}, \mathrm{CH}(\mathrm{Cy})\right), 27.0$ (s, $\mathrm{CH}(\mathrm{Cy})$ ), 26.0 (s, $\mathrm{CH}(\mathrm{Cy}))$. IR (neat, $\mathrm{cm}^{-1}$ ): 2927, 2851, 1448, 1430, 1378, 1259, 1169, 1019. HRMS (ESI $/ \mathrm{Q}-\mathrm{TOF})$ ) $\mathrm{m} / \mathrm{z}$ : $[3 \mathrm{a}+\mathrm{H}]^{+}$Calcd for $\mathrm{C}_{25} \mathrm{H}_{39} \mathrm{~N}_{3} \mathrm{P}^{+}$412.2876; Found 412.2888.

Preparation of $\mathbf{3 b}(\mathrm{R}=\mathrm{Et}): n$-BuLi in hexanes (1.6 M, $0.92 \mathrm{mmol}, 0.57 \mathrm{~mL}$ ) was added to a suspension of $\mathbf{2 b}(265 \mathrm{mg}, 0.92 \mathrm{mmol})$ in $\mathrm{Et}_{2} \mathrm{O}$ $(4 \mathrm{~mL})$ at $-78{ }^{\circ} \mathrm{C}$. The reaction mixture was allowed to slowly warm to room temperature and stirred overnight. The mixture was filtered to remove $\mathrm{LiCl}$ and the filtrate was evaporated to give a yellow oil (174 mg, $75 \%$ ). ${ }^{31} \mathrm{P}$ NMR (121.5 MHz, THF- $\mathrm{d}_{8}$ ): 37.3. ${ }^{1} \mathrm{H}$ NMR (300 MHz, THF- $\mathrm{d}_{8}$ ): 7.63 (br. s, $\left.1 \mathrm{H}, \mathrm{CH}-\mathrm{N}\right), 7.40\left(\mathrm{~d}, \mathrm{~J}_{H, H}=8.0\right.$ $\mathrm{Hz}, 1 \mathrm{H}, \mathrm{CH}(\mathrm{Ar})), 7.33\left(\mathrm{~d}, J_{H, H}=8.0 \mathrm{~Hz}, 1 \mathrm{H}\right.$, $\mathrm{CH}(\mathrm{Ar})), 6.99\left(\mathrm{t}, J_{H, H}=8.0 \mathrm{~Hz}, 1 \mathrm{H}, \mathrm{CH}(\mathrm{Ar})\right), 6.83$ $\left(\mathrm{t}, J_{H, H}=7.5 \mathrm{~Hz}, 1 \mathrm{H}, \mathrm{CH}(\mathrm{Ar})\right), 2.07\left(\mathrm{dq}, J_{H, H}=7.5\right.$ $\left.\mathrm{Hz}, J_{P, H}=12.5 \mathrm{~Hz}, 3 \mathrm{H}, \mathrm{CH}_{2}\right), 1.16\left(\mathrm{dt}, J_{H, H}=7.5\right.$ $\left.\mathrm{Hz}, J_{P, H}=15.5 \mathrm{~Hz}, 9 \mathrm{H}, \mathrm{CH}_{3}\right) .{ }^{13} \mathrm{C}\left\{{ }^{1} \mathrm{H}\right\}$ NMR $(75.5$ $\mathrm{MHz}, \quad \mathrm{THF}^{\left.-\mathrm{d}_{8}\right):} \quad 146.2 \quad\left(\mathrm{C}^{\mathrm{IV}}-\mathrm{N}\right), 123.0 \quad(\mathrm{~s}$, $\mathrm{CH}(\mathrm{Ar})), 122.8\left(\mathrm{~s}, \mathrm{C}^{\mathrm{IV}}-\mathrm{C}\right), 119.8(\mathrm{~s}, \mathrm{CH}(\mathrm{Ar})), 118.6$ (s, CH(Ar)), 115.9 (d, J $J_{P, C}=14.0 \mathrm{~Hz}, \mathrm{CH}-\mathrm{N}$ ), 115.3 (s, CH(Ar)), 18.2 (d, $J_{P, C}=61.5 \mathrm{~Hz}, \mathrm{CH}_{2}$ ), 6.54 (s, $\mathrm{CH}_{3}$ ). IR (neat, $\mathrm{cm}^{-1}$ ): 2969, 2937, 2878, 1502, 1452, 1430, 1377, 1258, 1168, 1040, 1015. HRMS (ESI $\left.{ }^{+} / \mathrm{Q}-\mathrm{TOF}\right) \mathrm{m} / \mathrm{z}$ : $[3 \mathbf{b}+\mathrm{H}]^{+}$Calcd for $\mathrm{C}_{13} \mathrm{H}_{21} \mathrm{~N}_{3} \mathrm{P}^{+}$250.1468; Found 250.1469.

Preparation of 3c (R=Ph): KHMDS (66 mg, 0.33 $\mathrm{mmol}$ ) was added to a solution of $\mathbf{2 c}(169 \mathrm{mg}$, $0.33 \mathrm{mmol}$ ) in THF ( $2 \mathrm{~mL})$. The solution became brown upon addition of KHMDS. After overnight stirring at room temperature, the reaction mixture was centrifugated. The solid was discarded and the solution evaporated to give a yellow oil. The oil was washed with pentane $(4 \mathrm{~mL})$ and dried to deliver $3 \mathrm{c}$ as a yellow solid (74 mg, $57 \%$ ). Single crystals of $3 \mathrm{c}$ were obtained by slow diffusion of pentane into a concentrated THF solution of the compound at $-35^{\circ} \mathrm{C}$. ${ }^{31} \mathrm{P}$ NMR $(121.5 \mathrm{MHz}$, THF$\left.\mathrm{d}_{8}\right): 11.3 \mathrm{ppm} .{ }^{1} \mathrm{H}$ NMR $\left(300 \mathrm{MHz}, \mathrm{THF}-\mathrm{d}_{8}\right): 7.89$ (dd, $J_{P, H}=12.0 \mathrm{~Hz}, J_{H, H}=7.0 \mathrm{~Hz}, 6 \mathrm{H}, \mathrm{CH}\left(\mathrm{PPh}_{3}\right)$ ), 7.83 (br. s, $1 \mathrm{H}, \mathrm{CH}-\mathrm{N}$ ), 7.51 (dt, $J_{H, H}=7.5 \mathrm{~Hz}, J_{P, H}=$ $\left.1.5 \mathrm{~Hz}, 3 \mathrm{H}, \mathrm{CH}\left(\mathrm{PPh}_{3}\right)\right), 7.42$ (qd, $J_{H, H}=7.5 \mathrm{~Hz}$, $\left.J_{P, H}=4.0 \mathrm{~Hz}, 6 \mathrm{H}\right), 7.39\left(\mathrm{~d}, J_{H, H}=7.0 \mathrm{~Hz}, 1 \mathrm{H}\right.$, $\mathrm{CH}(\mathrm{Ar})) 7.17$ (d, $\left.J_{H, H}=8.5 \mathrm{~Hz}, 1 \mathrm{H}, \mathrm{CH}(\mathrm{Ar})\right), 6.90$ (ddd, $J_{H-H}=8.5,7.5$ and $1.0 \mathrm{~Hz}, \mathrm{~Hz}, 1 \mathrm{H}, \mathrm{CH}(\mathrm{Ar})$ )), $6.79\left(\mathrm{t}, J_{H, H}=7.5 \mathrm{~Hz}, 1 \mathrm{H}, \mathrm{CH}(\mathrm{Ar})\right) .{ }^{13} \mathrm{C}\left\{{ }^{1} \mathrm{H}\right\} \mathrm{NMR}$ (75.5 MHz, THF-d d $_{8}$ : 144.5 (s, C CV-N), 133.3 (d, $\left.J_{P, C}=9.5 \mathrm{~Hz}, \mathrm{CH}\left(\mathrm{PPh}_{3}\right)\right), 131.7\left(\mathrm{~d}, J_{P, C}=3.0 \mathrm{~Hz}\right.$, $\left.\mathrm{CH}\left(\mathrm{PPh}_{3}\right)\right), 129.7\left(\mathrm{~d}, J_{P, C}=99.5 \mathrm{~Hz}, \mathrm{C}^{\mathrm{IV}}-\mathrm{P}\right), 128.1$ $\left(\mathrm{d}, J_{P, C}=12.0 \mathrm{~Hz}, \mathrm{CH}\left(\mathrm{PPh}_{3}\right)\right), 122.0(\mathrm{~s}, \mathrm{CH}(\mathrm{Ar}))$, $121.8\left(\mathrm{~d}, J_{P, C}=12.0 \mathrm{~Hz}, \mathrm{C}^{\mathrm{IV}}-\mathrm{C}\right), 118.9(\mathrm{~s}, \mathrm{CH}(\mathrm{Ar}))$, $117.6(\mathrm{~s}, \mathrm{CH}(\mathrm{Ar})), 115.5$ (d, $\left.\mathrm{J}_{P, C}=14.5 \mathrm{~Hz}, \mathrm{CH}-\mathrm{N}\right)$, 114.7 (s, CH (Ar)). IR (neat, $\mathrm{cm}^{-1}$ ): 3075, 1431, 1371, 1264, 1223, 1015. HRMS (ESI + Q-TOF) $\mathrm{m} / \mathrm{z}:[3 \mathrm{c}+\mathrm{H}]^{+}$Calcd for $\mathrm{C}_{25} \mathrm{H}_{21} \mathrm{~N}_{3} \mathrm{P}^{+} 394.1468$; Found 394.1479.

$X$-ray crystallography: Data were collected at $150 \mathrm{~K}$ on a Bruker Kappa APEX II diffractometer using a Mo-k $(\lambda=0.71069 \AA)$ X-ray source and a graphite monochromator. The crystal structures were solved using Shelxt ${ }^{15}$ or oleix ${ }^{16}$ and refined using Shelxl-97 or Shelxl-2014. ${ }^{17}$ ORTEP drawings were made using ORTEP III ${ }^{18}$ for Windows or Mercury. Details of crystal data and structure refinements are summarized in Table S1 and S2.

Computational details. The computations were performed using the Gaussian 09 software package. ${ }^{19}$ Following a recent report, ${ }^{20}$ the geometry of all compounds and transition states was optimized with the M06-2X functional $^{21}$ and the $6-31 \mathrm{G}(\mathrm{d})$ basis set. Frequency calculations furnished the thermal correction to the Gibbs free Energy $G_{\text {corr. }}$ Using the gas phase geometry, single point calculations at the M06-2X/6-311++G(2d,p) level were carried out to obtain the energies in solution $E_{S C R F}$ (IEF-PCM method with Bondi radii). ${ }^{22}$ The free energy in solution at $298 \mathrm{~K}$ was obtained by adding the single point energy to the thermal correction to the Gibbs free energy 
( $G=E_{\text {SCRF }}+G_{\text {corr }}$ ). The discussed free energies are $\Delta G_{298}$ in $\mathrm{kcal} / \mathrm{mol}$ in toluene.

\section{Supporting Information}

X-ray structures and the corresponding data, HR-mass and CID data, coordinates, energies and imaginary Frequencies of the computed cpecies, as well as NMR spectra.

\section{Acknowledgement}

Ecole polytechnique is thanked for financial support and PhD funding (TT), as well as CNRS and UPSaclay. This work was granted access to the HPC resources of CINES under the allocation 2020-A0070810977 made by GENCI. The GDR Phosphore is acknowledged for the organization of regular fruitful meetings, and Pr. Le Gendre and Dr. Canac for helpful discussion.

\section{References}

1. Staudinger, H. Meyer, J. Über neue organische Phosphorverbindungen III. Phosphinmethylenderivate und Phosphinimine. Helv. Chim. Acta 1919, 2, 635646.

2. (a) Johnson, A. W.; Kaska, W. C.; Starzewski, K. A. O. Dixon, D. A. Ylides ans imines of phosphorus. John Wiley \& sons: New York, 1993; (b) Tanimoto, H. Kakiuchi, K. Recent Applications and Developments of Organic Azides in Total Synthesis of Natural Products. Nat. Prod. Commun. 2013, 8, 1021-1034.

3. Köhn, M. Breinbauer, R. The Staudinger Ligation-A Gift to Chemical Biology. Angew. Chem. Int. Ed. 2004, 43, 3106-3116.

4. (a) Bock, H. Schnöller, M. Proof of NpNBElimination from Staudinger Adducts $\mathrm{R} 3 \mathrm{P}=\mathrm{N} \gamma$ $\mathrm{N} \beta=\mathrm{N} \alpha-X$ by ${ }^{15} \mathrm{~N}$-Isotopic Labeling. Angew. Chem. Int. Ed. 1968, 7, 636-636; (b) Tian, W. Q. Wang, Y. A. Mechanisms of Staudinger Reactions within Density Functional Theory. J.Org. Chem. 2004, 69, 4299-4308.

5. (a) Hillhouse, G. L. Haymore, B. L. Interaction of aryl azides with tungsten complexes. Three new types of reactions yielding coordinated $\mathrm{RN}_{3} \mathrm{PR}_{3}, \mathrm{RN}_{3} \mathrm{H}$, and RN. J. Organomet. Chem. 1978, 162, C23-C26; (b) Bebbington, M. W. P. Bourissou, D. Stabilised phosphazides. Coord. Chem. Rev. 2009, 253, 1248-1261; (c) Dickie, T.
K. K.; MacNeil, C. S. Hayes, P. G. Consecutive N2 loss from a uranium diphosphazide complex. Dalton Trans. 2020, 49, 578-582.

6. (a) Molina, P.; Arques, A. Vinader, M. V. Intramolecular trapping of a phosphazide by an imine: Formation of 2,3-diamino-2H-indazole derivatives from o-azidobenzaldimines and tertiary phosphines. Tetrahedron Lett. 1989, 30, 6237-6240; (b) Molina, P.; Arques, A. Vinader, M. V. Iminophosphorane-mediated synthesis of $2 \mathrm{H}$-indazole derivatives: preparation of 2,3-diamino-2H-indazoles by intramolecular trapping of phosphazides and 1H-1,2,4-triazolo[2,3-b]indazoles by a tandem aza-Wittig/heterocumulene-mediated

strategy. J. Org. Chem. 1990, 55, 4724-4731; (c) Molina, P.; Arques, A.; Cartagena, I. Obon, R. The Staudinger reaction of oazidobenzaldehyde with triphenylphosphine revisited influence of the temperature on the nature of the reaction products. Tetrahedron Lett. 1991, 32, 2521-2524; (d) Molina, P.; Arques, A.; Alias, A.; Vinader, M. V.; Focesfoces, M. C. Hernandezcano, F. Preparation, reactivity and synthetic applications of bis(iminophosphoranes): new entries to fused 1,3,5-benzotriazepines, 1,3-benzodiazepines and indole derivatives. Tetrahedron 1992, 48, 3091-3110; (e) Molina, P.; Conesa, C.; Alias, A.; Arques, A.; Velasco, M. D.; Llamassaiz, A. L. Focesfoces, C. Preparation and synthetic applications of iminophosphoranes derived from o-substituted arylazides: preparation of pyrazolo[1,2-b]indazole, $4 \mathrm{H}-3,1$-benzoxazine and quinoline derivatives. Crystal structure of 2-[2-(4-methoxybenzoylamino)phenyl]-4-

methylquinoline. Tetrahedron 1993, 49, 75997612; (f) Fresneda, P. M.; Castaneda, M.; Sanz, M. A.; Bautista, D. Molina, P. An iminophosphorane-based approach for the synthesis of spiropyrrolidine-imidazole derivatives. Tetrahedron 2007, 63, 1849-1856; (g) Myers, E. L. Raines, R. T. A PhosphineMediated Conversion of Azides into Diazo Compounds. Angew. Chem. Int. Ed. 2009, 48, 2359-2363; (h) Taylor, S. D. Lohani, C. R. A Fresh Look at the Staudinger Reaction on Azido Esters: Formation of 2H-1,2,3-Triazol-4-ols from alpha-Azido Esters Using Trialkyl Phosphines. Org. Lett. 2016, 18, 4412-4415.

7. (a) Cavell, R. G. Metal complexes of diphosphorus imines. An exploration of 
multifunctional phosphorus-nitrogen ligandmetal chemistry. Curr. Sci. 2000, 78, 440-451; (b) Cariou, R.; Graham, T. W.; Dahcheh, F. Stephan, D. W. Oxidative addition of aryl halides: routes to mono- and dimetallic nickel amino-bis-phosphinimine complexes. Dalton Trans. 2011, 40, 5419-5422; (c) Garcia-Alvarez, J.; Garcia-Garrido, S. E. Cadierno, V. Iminophosphorane-phosphines: Versatile ligands for homogeneous catalysis. J. Organomet. Chem. 2014, 751, 792-808; (d) Mazaud, L.; Tricoire, M.; Bourcier, S.; Cordier, M.; Gandon, V. Auffrant, A. Tridentate NNN Ligand Associating Amidoquinoline and Iminophosphorane: Synthesis and Coordination to $\mathrm{Pd}$ and $\mathrm{Ni}$ Centers. Organometallics 2020 and references cited therein.

8. Vetter, A. C.; Nikitin, K. Gilheany, D. G. Long sought synthesis of quaternary phosphonium salts from phosphine oxides: inverse reactivity approach. Chem. Commun. 2018, 54, 58435846.

9. Habraken, E. R. M.; van der Zee, L. J. C.; van de Vrande, K. N. A.; Jupp, A. R.; Nieger, M.; Ehlers, A. W. Slootweg, J. C. Facile Synthesis of Tuneable Azophosphonium Salts. Eur. J. Inorg. Chem. 2019, 1594-1603.

10. Winkelhaus, D.; Holthausen, M. H.; Dobrovetsky, R. Stephan, D. W. Phosphine and carbene azido-cations: $\left[(\mathrm{L}) \mathrm{N}_{3}\right]^{+}$and $\left[(\mathrm{L})_{2} \mathrm{~N}_{3}\right]+$. Chem. Sci. 2015, 6, 6367-6372.

11. Zhou, J.; Liu, L. L.; Cao, L. L. Stephan, D. W. An umpolung of Lewis acidity/basicity at nitrogen by deprotonation of a cyclic (amino)(aryl)nitrenium cation. Chem. Commun. 2018, 54, 4390-4393.

12. (a) Krannich, L. K.; Kanjolia, R. K. Watkins, C. L. Synthesis and characterization of some aminophosphonium chlorides. Inorg. Chim. Acta 1985, 103, 1-8; (b) Krannich, L. K.; Kanjolia, R. K. Watkins, C. L. ${ }^{13} \mathrm{C}$ and ${ }^{31} \mathrm{P}$ NMR studies of some aminophosphonium chlorides. Magn. Reson. Chem. 1987, 25, 320-324.

13. This is consistent with previously reported computations ref. $4 \mathrm{~b}$.

14. Kim, H. Chang, S. Intramolecular Amido Transfer Leading to Structurally Diverse Nitrogen-Containing Macrocycles. Angew. Chem. Int. Ed. 2017, 56, 3344-3348.
15. Sheldrick, G. SHELXT - Integrated spacegroup and crystal-structure determination. Acta Cryst. A 2015, 71, 3-8.

16. Dolomanov, O. V.; Bourhis, L. J.; Gildea, R. J.; Howard, J. A. K. Puschmann, H. OLEX2: a complete structure solution, refinement and analysis program. J. Appl. Crystallogr. 2009, 42, 339-341.

17. Sheldrick, G. Crystal structure refinement with SHELXL. Acta Cryst. C 2015, 71, 3-8.

18. Farrugia, L. J. ORTEP-3 program, Department of Chemistry, University of Glasgow: 2001.

19. Frisch, M. J.; Trucks, G. W.; Schlegel, H. B.; Scuseria, G. E.; Robb, M. A.; Cheeseman, J. R.; Scalmani, G.; Barone, V.; Petersson, G. A.; Nakatsuji, H.; Li, X.; Caricato, M.; Marenich, A. V.; Bloino, J.; Janesko, B. G.; Gomperts, R.; Mennucci, B.; Hratchian, H. P.; Ortiz, J. V.; Izmaylov, A. F.; Sonnenberg, J. L.; WilliamsYoung, D.; Ding, F.; Lipparini, F.; Egidi, F.; Goings, J.; Peng, B.; Petrone, A.; Henderson, T.; Ranasinghe, D.; Zakrzewski, V. G.; Gao, J.; Rega, N.; Zheng, G.; Liang, W.; Hada, M.; Ehara, M.; Toyota, K.; Fukuda, R.; Hasegawa, J.; Ishida, M.; Nakajima, T.; Honda, Y.; Kitao, O.; Nakai, H.; Vreven, T.; Throssell, K.; J. A. Montgomery, J.; Peralta, J. E.; Ogliaro, F.; Bearpark, M. J.; Heyd, J. J.; Brothers, E. N.; Kudin, K. N.; Staroverov, V. N.; Keith, T. A.; Kobayashi, R.; Normand, J.; Raghavachari, K.; Rendell, A. P.; Burant, J. C.; Iyengar, S. S.; Tomasi, J.; Cossi, M.; Millam, J. M.; Klene, M.; Adamo, C.; Cammi, R.; Ochterski, J. W.; Martin, R. L.; Morokuma, K.; Farkas, O.; Foresman, J. B. Fox, D. J., Gaussian 09, Revision D.01. Gaussian inc., Wallingford CT, 2016.

20. Zhou, J.; Cao, L. L.; Liu, L. Stephan, D. W. FLP reactivity of $\left[\mathrm{Ph}_{3} \mathrm{C}\right]^{+}$and (o-tolyl) $)_{3} \mathrm{P}$ and the capture of a Staudinger reaction intermediate. Dalton Trans. 2017, 46, 9334-9338.

21. Zhao, Y. Truhlar, D. G. The M06 suite of density functionals for main group thermochemistry, thermochemical kinetics, noncovalent interactions, excited states, and transition elements: two new functionals and systematic testing of four M06-class functionals and 12 other functionals. Theor. Chem. Acc. 2008, 120, 215-241.

22. Bondi, A. van der Waals Volumes and Radii. J. Phys. Chem. 1964, 68, 441-451. 